\title{
Lena Mirošević
}

ORCID: https://orcid.org/0000-0002-8016-9783

Arkadiusz Krasicki

ORCID: https://orcid.org/0000-0002-6229-5233

Josip Faričić

ORCID: https://orcid.org/0000-0002-8235-1917

University of Zadar, Croatia

\section{Symbolism of the Rural and Suburban Landscape of the Holy Land in the New Testament}

\begin{abstract}
The article discusses the symbolism of the rural and suburban landscape of the Holy Land in the New Testament. Based on the results of previous geographical and theological (exegetical) research of certain elements of the natural and cultural landscape, and studies of biblical texts and descriptions of landscape motifs in areas where Jesus Christ lived and worked, the article attempts to point out the symbolism that enriches mere facts about the geographical reality of the Holy Land. It has been determined that the most important natural-geographical forms and phenomena are clearly recognized in the rural and suburban landscape of the Holy Land, while the identity of the Jewish community formed by different human activities and ways of life is imprinted in the cultural landscape, which includes a related web of multiple dualities: the real and the imaginary, the natural and the supernatural, and the material and the spiritual.
\end{abstract}

\section{Keywords}

Landscape, Bible, New Testament, Holy Land. 


\section{Introduction}

Landscapes are the subject of research within various scientific disciplines. While the forms of various physical-geographical elements are seen in the natural landscape, primarily in reliefs, soil, water, flora, etc. which are all interrelated with the climate, the cultural landscape reflects human presence and activity. C. Sauer succinctly sublimates the relationship between culture and nature when defining the cultural landscape: Culture is the agent, nature is the medium, and the cultural landscape is the result. ${ }^{1}$ Such interactions are observed in the temporal context through observing (non)changes in the physiognomic features of the landscape and emotional connections in which the landscape takes on a symbolic meaning. In rural and suburban landscapes, natural elements are particularly pronounced; given the high dependence of the economy in which agricultural activities, based on the characteristics of the relief, soil, climate and water, predominate.

Landscape is observed not only through material traces imprinted in space, but also through the complexity of its interpretation. This interpretation depends on the depth and breadth of insights that contribute to the understanding and contextualization, and the perception of space which, in addition to insights, is significantly influenced by the perspective from which the landscape is observed and considered. Therefore, the cultural landscape can be interpreted as the announcement, publication and exposure of data on social groups that inhabit a particular area. ${ }^{2}$ The cultural landscape consists of various forms of visible reality, but it also contains layers of information about the value systems, inclinations, beliefs, fears, and truths of its creators. Each component of the landscape has its own features, imbued with numerous perceptions and memories. In this way, the identity of the community formed by various human activities and ways of life is imprinted in the landscape, along with the intertwined network of multiple dualities: the real and the imaginary, the natural and the supernatural, and the material and the spiritual. Landscapes are therefore a challenge and an inexhaustible source for study, though it is difficult to expect

${ }^{1}$ C. Sauer, The Morphology of Landscape, in: J. Sgnew, D. N. Livingstone, A. Rogers (eds), Human Geography. An Essential Anthology, Oxford 1996 [1925], Blackwell, p. 310; L. Šakaja, Uvod u kulturnu geografiju (Introduction to Cultural Geography), Zagreb 2015, Leykam international, pp. 73-75.

${ }^{2}$ F. Bellentani, Landscape as text. in: C. J. R. Higuera, T. J. Bennett (eds.), Concepts for Semiotics, Tartu 2016, University of Tartu Press, pp. 76-87. 
an interpretation - the decoding of a landscape - which enables it to be fully understood. Like any semiosis, it is a process that, in addition to the sign and the item indicated, always includes the interpreter, ${ }^{3}$ and no matter how much the methodological patterns of each of the scientific disciplines try to objectify approaches to studying landscapes, a subjective tone cannot be avoided.

There are several key factors that shape and interpret the rural and suburban landscapes, one of them being religion. This is a universal phenomenon that is present to varying degrees in all societies. There are many implications of the interaction of religion and space. ${ }^{4}$ The interaction of landscapes and religion is manifested through the influence of landscape patterns on religious motifs and models, and at the same time through the spatial manifestations of religious beliefs and rituals that shape cultural landscapes. ${ }^{5}$ Many natural and cultural elements of landscapes take on the characteristics of holiness, and so sacred places and sacred spaces are gradually established in religions, from hills and caves to lakes and rivers, from monumental architectural forms (temples, cathedrals, etc.) to smaller and simpler religious features (stone or wooden crosses). At the same time, religious elements in the landscape contribute to spatial organisation. For example, important sacred buildings (cathedrals, parish churches, shrines) are often located in the centre of settlements to which main roads lead, while bell towers serve as landmarks and an expression of God's power, but also as architectural achievements, and as signs of the social and economic strength of the communities that erected them.

Sources of knowledge about landscapes, that is, the notion of a geographical reality, can be material and written. Regardless of the spirit of the time, the form, or the medium on which texts are written, they are valuable as historical sources, since they provide a multitude of facts, and are often the key to interpreting those facts, allowing for well-argued discussions. Written sources on various spatial objects, structures and systems, whether reports, study results or literary

E. Casti, Towards a theory of interpretation: cartographic semiosis, "Cartographica: The International Journal for Geographic Information and Geovisualization” 40 (2005) 3, pp. 1-16.

L. Kong, Religious Landscapes, in: J. S. Duncan; N. C. Johnson, R. H. Schein (eds.), A Companion to Cultural Geography, Malden, Oxford and Carlton 2004, Blackwell Publishing, pp. 365-381. J. D. Dewsbury, P. Cloke, Spiritual landscapes: existence, performance and immanence, "Social \& Cultural Geography", 10 (2009) 6, pp. 695-707.

D. E. Sopher, Geography of religions, Englewood Cliffs 1967, Prentice-Hall, pp. 24-46; Ch. C. Park, Sacred worlds. An Introduction to geography and religion, London and New York 1994, Routledge, pp. 197-244. 
works, contain valuable information about landscapes, often describing those that no longer exist, and thus complementing the corpus of geographical knowledge. ${ }^{6}$ The geographical images obtained in this way do not only consist of mere facts, but are filled out with signs and nuances of different approaches, and sometimes prejudices, thus influencing the (sub)conscious creation of images and ideas about the self and others. In this way, they contribute to the creation of an imaginative geography that is intertwined with the real one, and it is not always easy to separate them.

In this context, an immeasurable importance should certainly be ascribed to the Bible; a complex collection of books of quite different genres and styles, with known and unknown authors who wrote about the history of salvation throughout the ten centuries, narrating about the space and time in which the decisive events of God's revelation to the chosen people, as well as all other nations, took place. In addition to the primary roles of the Old and New Testaments that were exegetically interpreted in different traditions and with different approaches, the Bible began to be used very early on, and systematically from the Renaissance, as a source of information about space, and so a separate discipline was gradually established - biblical geography. In relation to this new discipline, cartographic representations have played a significant role in introducing the complex geography of the Holy Land to a wide circle of readers/users in the 16th and the 17 th century, enabling them to acquire a complete image of biblical texts that referred to specific places in the Holy Land, as well as in the neighbouring regions of the Middle East with Mesopotamia, northeast Africa, Asia Minor and the European part of the Mediterranean.

${ }^{6}$ L. Šakaja, Uvod u kulturnu geografiju (Introduction to Cultural Geography), Zagreb 2015, Leykam international, p. 253. 
Lena Mirošević, Arkadiusz Krasicki, Josip Faričić Symbolism of the Rural and Suburban Landscape of the Holy Land in the New Testament

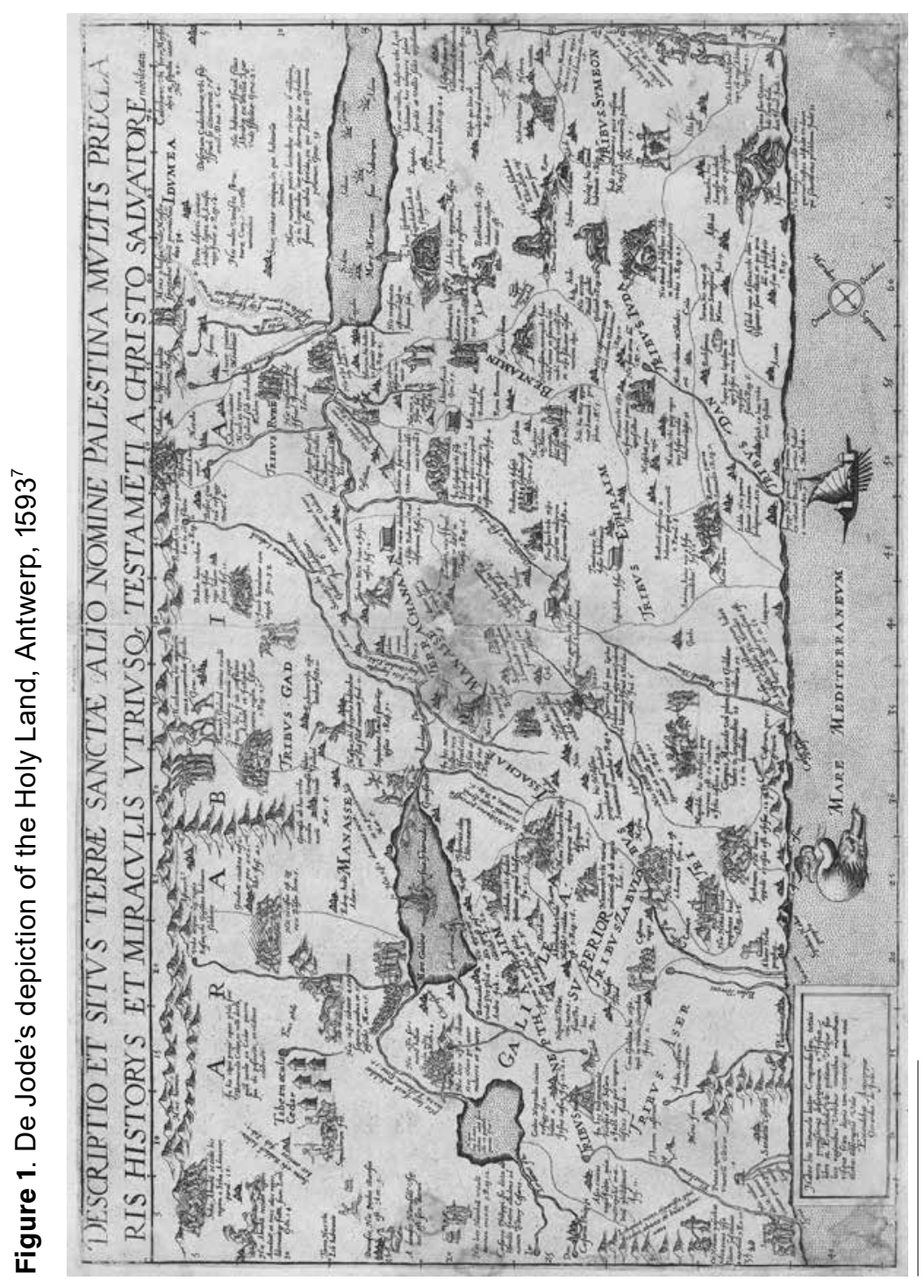

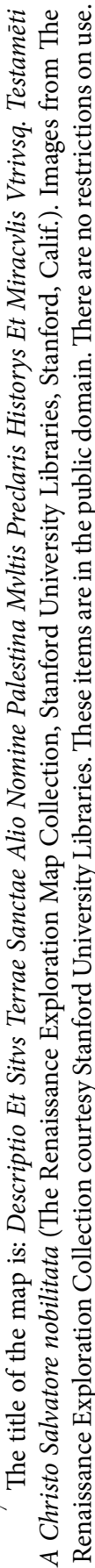


Methodological aspects of the study of landscape based on the quotations from the Bible have been defined in the existing vast biblical-geographic literature which is literally immense. The geographically relevant results of biblicalarchaeological research should be added to this. ${ }^{8}$ Among the many accomplishments, the work of Y. Acharoni ${ }^{9}$ stands out, as well as recent contributions, primarily those of M. Har-El, who discusses the relationship between man and nature in the Old Testament, ${ }^{10} \mathrm{E}$. F. Davis who writes about the basic features of land use in Palestine and the motifs that arise from it in biblical texts, ${ }^{11}$ and the especially exhaustive analysis of the area of Galilee in which Jesus spent most of his life, written by J. Vonder Bruegge, ${ }^{12}$ heavily based on sources (primarily the Gospels of Luke and John, and works by the historian Josephus), which follows the discourse of critical geography and the concept of spatiality. In addition to these books, it is necessary to highlight the informative overview of physical-geographical and human-geographical contents and context in the New Testament given by G. Alphin in his dissertation. ${ }^{13}$

H. Moxnes wrote about certain aspects of the geographical space of Jesus' life and work in several publications, and raised the issue of the construction of Galilee in 19th century works which tried to diminish or completely erase the Jewish character of that region within anti-Semitic ideological frameworks, ${ }^{14}$

${ }^{8}$ M. Piccirillo, Ricerca archeologica e Vangelo e i Luoghi Santi di Palestina, "Cauriensia" 3 (2008), pp. 53-91.

${ }^{9}$ Y. Aharoni, The Land of the Bible. A Historical Geography, translated from the Hebrew and edited by A. F. Rainey, Philadelphia 1979, Westminster Press.

${ }^{10}$ M. Har-El, Landscape, Nature and Man in the Bible: Sites and Events in the Old Testament, Jerusalem 2003, Carta.

${ }^{11}$ E. F. Davis, Scripture, Culture, and Agriculture, Cambridge 2008, Cambridge University Press.

2 J. Vonder Bruegge, Mapping Galilee in Josephus, Luke, and John. Critical Geography and the Construction of an Ancient Space, Ancient Judaism and Early Christianity, Volume 93, Leiden and Boston 2016, Brill.

${ }^{13}$ G. Alphin, A New Testament Geography: Description, Perspectives, and Implications for the Field of Geography, Baton Rouge, 2001, Louisiana State University.

${ }^{14}$ H. Moxnes, Placing Jesus of Nazareth: Toward a Theory of Place in the Study of the Historical Jesus, in S. G. Wilson, M. Desjardins (eds.), Text and Artifact in the Religions of Mediterranean Antiquity: Essays in Honour of Peter Richardson, Waterloo 2000, Wilfred Laurier University, pp. 158-75; H. Moxnes, The Construction of Galilee as a Place for the Historical Jesus - Part I, „Biblical Theology Bulletin” 31 (2001) 1, pp. 26-37; H. Moxnes, The Construction of Galilee as a Place for the Historical Jesus - Part II, „Biblical Theology Bulletin” 31 (2001) 2, pp. 64-77; H. Moxnes, Landscape and Spatiality: Placing Jesus, in: D. Neufeld, R. De 
while New Testament landscapes were considered by E. C. Stewart within the theory of space and spatiality. ${ }^{15} \mathrm{An}$ important theoretical contribution to the study of biblical geography with regards to new spatial theories was given by T. B. Dozeman, ${ }^{16}$ while a very valuable overview of contemporary geographical, theological and philosophical research on space and place in the Bible was provided by Patrick Schreiner. ${ }^{17}$

\section{The Bible as a source of knowledge about space}

The metaphor of landscape as text in social geography includes various concepts and approaches in interpreting landscapes. ${ }^{18}$ Landscapes as texts are always exposed to potential multiple meanings by creators and interpreters. Thus, the textuality of landscape has no historical or temporal boundaries. In the Bible, landscape takes on a symbolic meaning created by social groups in a particular geographical setting. This is especially expressed in the New Testament through the Gospels, which describe the life of Jesus Christ. Certain elements of the landscape that forms the background of the daily lives of the Jewish people and other inhabitants of the Roman province of Judea, take on an aspect of holiness, due to Jesus' touch (his immediate presence and saving activity).

The life and work of Jesus Christ in the Gospels are depicted through the daily culture of life at that time. Images of the biblical rural and suburban landscape are composed of elements of the natural landscape, but also of the anthropogenic landscape created by the economic (agriculture) and social (customs and habits)

Maris (eds.), Understanding the Social World of the New Testament, New York 2010: Routledge, pp. 90-106.

${ }^{15}$ E. C. Stewart, Gathered Around Jesus: An Alternative Spatial Practice in the Gospel of Mark, Cambridge, 2009, James Clark and Co.; E. C. Stewart, New Testament space/spatiality, "Biblical Theology Bulletin” 42 (2012) 3, pp. 139-150.

${ }^{16}$ T. B. Dozeman, Biblical Geography and Critical Spatial Studies, in: J. L. Berquist, C. V. Camp (eds.), Construction of Space I: Theory, Geography and Narrative, Library of Hebrew Bible - Old Testament Studies, 481, New York and London 2008, T\&T Clark, pp. 87-108.

${ }^{17}$ P. Schreiner, Space, place and biblical studies: A survey of recent research in light of developing trends, „Currents in Biblical Research” 14 (2016) 3, pp. 340-371.

${ }^{18}$ D. Cosgrove, S. Daniels, The Iconography of Landscape, Cambridge 1988, Cambridge University Press; W. Norton, Cultural Geography, Oxford 2006, Oxford University Press. 
interactions of individuals in the community. In this manner, through the New Testament, holiness is manifested in the hill, but also in the wine (with images of wine as existential nourishment and the vineyard as the space in which revelation takes place). The desert, the elevation and water, as well as olives, wine and pastoral motifs, become a symbolic construct in the sacralised landscape. These new poetic landscapes reflect the importance of biblical events and the significance of religion for the community.

Observing the landscape in the context of holiness is a complex process, as there is no simple answer to the question of what defines holiness. Furthermore, different religions choose their holy places using different criteria that can change over time. Moreover, sacred places are not transferable and do not have to be re-established over time. ${ }^{19}$ The religious expression of sacred space varies greatly in space and time. In addition to geography, an essential role in the process of sacralisation is ascribed to social groups that participate in the activities and processes of creating and marking the sacred according to the paradigm of their belief systems. ${ }^{20}$

\subsection{Symbolism of selected elements of the natural landscape in the New Testament}

The natural landscape of the Holy Land was the basis for the creation and shaping of experiences and meanings in the symbolic interpretation of the landscape. In this context, the presence of the desert is not surprising as a geographical reality, but also as a symbol in the Old Testament (the religion of the Israelites) and in the Christian world of the New Testament. Thus, the desert (Greek: है $\rho \eta \mu \varsigma$ ) denotes an empty place, or a desolate, lonely place (Mt 14:13; Mk 1:35, 45; Lk 4:42; 9:10), a place of desolation and orphans ( $G a l$ 4:27), a place where no one lives (Mt 3:3; 24:26; Lk 3:2; 4:1; 7:24; Jn 11:54; Rev 12:6,14; 17:3), but also a place of pride, victory and shame ( $\mathrm{Col} 2: 15)$.

${ }^{19}$ C. Park, Religion and geography, in: J. R. Hinnells (ed.), The Routledge Companion to the Study of Religion, London 2004, Routledge, pp. 439-455.

${ }^{20}$ L. Kong, Religious Landscapes, in: J. S. Duncan; N. C. Johnson, R. H. Schein (eds.), A Companion to Cultural Geography, Malden, Oxford and Carlton 2004, Blackwell Publishing, pp. 365-381; S. E. Kraft, The making of a sacred mountain. Meanings of nature and sacredness in Sápmi and northern Norway, "Religion" 40 (2010), pp. 53-61. 
The Gospel writers offer a two-dimensional meaning of the desert: it is the name of a geographical object ${ }^{21}$ inscribed in the geographical history of Israel, and at the same time it is a spiritual dimension expressed through symbolism from the very beginning of the history of the chosen people. The New Testament recognizes the desert as a place of temptation. The biblical text does not denote any particular place in the desert by name, but approaches it in a spiritual way. It becomes a symbol of temptation for everyone who believes in Jesus' messianic mission (cf. Lk 4:1). Therefore, demons also live in the desert (cf. Mt 4:1-8). The desert is also a place where God prepares and shapes leaders for his people. ${ }^{22}$ After the revelation to Moses in the desert and after Jesus's temptation, the desert becomes a place of victory and encountering God. ${ }^{23}$ Therefore, the desert carries within it the sign of a time of grace and salvation for Israel in a historical context, but also for all people in a spiritual context. It is where John the Baptist and Jesus retreated to be alone with God. According to the Jewish theological circles, the Messiah is supposed to come from the desert. The Qumran community was proof of that. ${ }^{24}$ So, the desert has an ambivalent symbolism; positive (contemplation/victory) and negative (wilderness/punishment). Already in the earliest Christian communities the symbolism of the desert had a strong spatial manifestation. Retreating into the desert and the desert experience formed a central experiential element of monastic communities. This shift affected the increasingly significant positive symbolism of the desert as a place of discovery or encounter with God. ${ }^{25}$ The redefined role of the desert as a meadow of silence, present in the medieval Christian tradition, influenced the spatial location of monastic monasteries throughout Europe. In this case, solitude and silence become crucial criteria when choosing the location of the monastery.

Elevations stand out as the highest, most impressive features of the landscape. The symbolism of elevations, especially mountains, includes the oldest

${ }^{21}$ J. Burić, Život i običaji Svete zemlje u Isusovo vrijeme (The life and customs of the Holy Land at the time of Jesus), Split 1998, Crkva u svijetu (Church in the World), p. 186.

${ }^{22}$ J. R. Dickson, Deserts of Development: How God Shapes His Leaders in the Wilderness, Doctoral thesis, Lynchburg, 2009, Liberty University.

${ }^{23}$ D. Fouilloux, Rječnik Biblijske kulture (Dictionary of Biblical Culture), Zagreb 1999, AGM, p. 177.

${ }^{24}$ A. Grabner-Haider (ed.), Praktični biblijski leksikon (A practical biblical lexicon), Zagreb 1997, Kršćanska sadašnjost, pp. 340-341.

${ }^{25}$ B. McGinn, Ocean and Desert as Symbols of Mystical Absorption in the Christian Tradition, “The Journal of Religion" 74 (1994) 2, pp. 155-181. 
and most widespread images in the history of mankind. The earliest civilizations, such as the Sumerians who built ziggurats (multi-storey temples), or the Egyptians who built pyramids in the shape of hills, believed that they were the abodes of the gods. Due to their morphology, mountains evoke a sense of awe and power, and at the same time symbolise perseverance, eternity, stability and calm. The presence of the mountain in almost all cultures and religions is therefore not surprising. Elevations (in the Bible, Greek: öpoc) are a common feature in the landscape of the Holy Land. In addition to their significance as the main constructive element of the landscape, elevations (mountains, hills) carry a great symbolic meaning as well. They touch the sky, and their tops are the links between heaven and earth, God and man. They are therefore both sanctuaries and altars. ${ }^{26}$ Ascension is the expression of a religious act. In this context, high places are very often present in the Old and New Testaments, where the heights of Sinai and Zion stand out, where the name Zion does not denote a district of Jerusalem, but mostly alludes to the Heavenly Jerusalem. ${ }^{27}$

The first hill mentioned in the New Testament is the Mount of Temptation. According to tradition, the steep Quarantania Hill (Gebel Quarantal) was 492 metres high, with many caves. According to the biblical account, Jesus spent 40 days there while he was tempted by the devil. He fasted for forty days and forty nights (Mt 4:1-11; Mk 1:12-13; Lk 4:1-13). The Hill of Choice, for which no specific oronym is recorded in the Gospels, is most likely one of the hills near the Sea of Galilee. ${ }^{28}$ According to the Gospels, after the Mount of Temptation, Jesus went to another mountain to pray (Lk 6:12). The Mount of the Beatitudes is the hill that the evangelist Matthew calls "the mountain” (Mt 5:1). The discourse on the Mount of the Beatitudes is found in two places: Matthew 5:3-12 and Luke 6:20-23. In Jesus' speech, the beatitudes have a special connotation. The beatitudes are found at the beginning of the great Sermon on the Mount, and thus point to the proclamation of Jesus. All who are rejected, oppressed,

${ }^{26}$ M. Cocagnac, Biblijski simboli (Biblical Symbols), Zagreb 2002, Antibarbarus, p. 89.

${ }^{27}$ R. T. France, A tale of two mountains: mountains in biblical spirituality, "Rural Theology" 6 (2008) 2, pp. 117-125.

${ }^{28}$ It should be noted that the Gospel writers sometimes do not use the names of hills or mountains deliberately for theological reasons. On the other hand, this does not imply that the hills mentioned in the Gospels did not have their own names or that they do not have them today. J. Burić, Život i običaji Svete zemlje u Isusovo vrijeme (The life and customs of the Holy Land at the time of Jesus), Split 1998, Crkva u svijetu (Church in the World), p. 185. 
or poor become blessed. Certainly, within Jesus' speech there lies a paradoxical situation which, in Jesus' eyes, has a happy ending.

In the tradition of the Church from the 4th century, Mount Tabor is identified as the hill of the Transfiguration of Jesus. However, none of the gospels mention the name Tabor, it is related to the events from the Old Testament, the Period of Judges. This hill (Mt 17:1; Mk 9:2; Lk 9:28) is located in southern Galilee and, with an average height of $600 \mathrm{~m}$, is the highest in that part of the Holy Land a wooded area intersected by fertile bays and valleys. The mount is massive and surrounded by flat terrain, so its relative height stands out. It rises in the middle of the fertile Jezreel valley in the shape of a cone. ${ }^{29}$ The place of Jesus' transfiguration is mentioned in the Gospels as a "high mountain" (Mt 17:1; Mk 9:2) or simply a mountain (Lk 9:28). During the Transfiguration, Jesus meets Moses and Elijah. They too achieved direct communication with God in an elevated place. Moses met God on Mount Horeb (Ex 3:5), as did Elijah (1 Kgs 19:7-15). This points to the fact that prominent heights are dominant elements of the landscape and are regularly associated with God's presence. Due to the orographic effect of water vapour condensing and moist air rising in higher zones with lower air temperature, low clouds form over peaks. These clouds are often a sign of God's presence touching the earth in Holy Scripture, as confirmed by Isaiah 66:1, and in the New Testament by the writer of the Acts of the Apostles (Acts 7:48-49): "Heaven is my throne, and the earth is my footstool. What kind of house should you build for me, says the Lord, or what is the place of my rest?"

The Mount of Olives is located east of Jerusalem. There Jesus wept over Jerusalem (Lk 19:41-44) and there he was arrested and taken to court (Mt 26:36-46; Mk 14:32-42; Lk 22:29-46; Jn 12:27). The Mount of Olives remained the site of Jesus's suffering and tribulations before his death. The hill is about 800 metres high. According to exegetical interpretation, Jesus is like an olive tree (whose fruits 'spill' oil), ready to spill his blood. This is corroborated by the proximity of Gath Shemanim (שמנים ת) olive grove where an olive press is located. ${ }^{30}$

The olive grove, where Jesus endures dramatic moments, symbolises life. The olive is a long-lived tree, resistant to the climate extremes of the Mediterranean and an important source of oil used for food, as fuel for lighting of fire, and on rare

${ }^{29}$ J. Burić, Život i običaji Svete zemlje u Isusovo vrijeme (The life and customs of the Holy Land at the time of Jesus), Split 1998, Crkva u svijetu (Church in the World), p. 185.

${ }^{30}$ See. R. Schnackenburg, Evanđelje po Marku (Gospel of Mark), Volume 2, Zagreb 2018, Glas koncila, pp. 248-249. 
and especially solemn occasions, for consecration. It is a very common cultivated plant in the Holy Land and throughout the Mediterranean, and has become an essential symbol of almost all the religions that have developed in the area.

The original symbol of life and one of the basic elements is water. In the past, but also today, many human populations around the world are connected by rivers. Rivers connect people and places, inspiring and maintaining different cultural beliefs, values and ways of life. ${ }^{31}$ In the Bible, as in most ancient, especially hydraulic (river-based) civilizations, water symbolises creation and purification. The universal symbolic aspects of water are rebirth, renewal, growth, fertility (biological and agrarian), etc. Water gives life to people, plants and animals, and is also a means of cleansing. Physical cleansing is associated with spiritual purification, and ritual immersion with new, and renewed life. The streams and springs of water in the Bible are places of encounter, that is, places of purification, renewal, and immortality. The power of renewal is particularly highlighted through the Great Flood, in which water washes away wickedness, erases evil, and at the same time enables a new beginning for humanity. The symbolism of regeneration has been retained in the rite of baptism, and at the entrances and exits of Christian churches. ${ }^{32}$

There are numerous references to water in the Bible, whether specific sources of water or the symbolism of water. ${ }^{33}$ Among all the occurrences of water, the River Jordan is the most mentioned, as it had the greatest significance for the Holy Land, and functioned like a hydrological axis around which many key events happened in the history of the Jewish people. In the Old Testament, it is associated with important moments related to the arrival in the Promised Land and the salvation of the people of Israel. In the New Testament, this river is associated with important events related to the prophetic work of John the Baptist and the messianic teachings of Jesus Christ. In Matthew (3:4-6; 13-16)

${ }^{31}$ E. P. Anderson, S. Jackson, R. E. Tharme, M. Douglas, J. E. Flotemersch, M. Zwarteveen, C. Lokgariwar, M. Montoya, A. Wali, G. T. Tipa, T. D. Jardine, J. D. Olden, L. Cheng, J. Conallin, B. Cosens, C. Dickens, D. Garrick, D. Groenfeldt, J. Kabogo, D. J. Roux, A. Ruhi, A. H. Arthington, Understanding rivers and their social relations: A critical step to advance environmental water management, WIREs Water, 2019; 6:e1381, pp. 1-21.

${ }^{32}$ P. Stokowski, Symbolic Aspects of Water, in: S. F. McCool, R. N.Clark, G. H. Stankey (eds.), Water and people: challenges at the interface of symbolic and utilitarian values, Gen. Tech. Rep. PNW-GTR-729. Portland 2008, Portland, OR: U.S. Department of Agriculture, Forest Service, Pacific Northwest Research Station, pp. 19-60.

${ }^{33}$ K. Višaticki, Z. Pažin, Živa Voda-Majim Hajim (Living Water - Majim Hajim), Zagreb 2008, Teovizija, p. 104. 
we read that Jesus was baptised by John in the River Jordan. Tradition has it that the place of his baptism was near Jericho, though John baptised along the entire Jordan Valley. ${ }^{34}$ There is no clear information about this in the Gospels, so another possibility is that Jesus was baptized on the upper reaches of the Jordan, closer to Nazareth. Another place where Jesus arrived at the Jordan is one of its sources in the rural surroundings of Caesarea Philippi (Mk 8:27-30). ${ }^{35}$

Of the smaller watercourses, the Kidron stream is the only one mentioned in the Gospels. The Kidron flows east of Jerusalem along the Mount of Olives. Along this stream, in the Garden of Gethsemane, Jesus' arrest took place (Jn 18:3).

Other than rivers, wells were important points of water supply, and therefore also meeting-places. The Gospel of John (Jn 4:1-54) tells of Jesus' encounter with

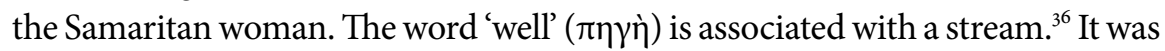
Jacob's Well (cf. Jn 4:1), located in the area of Shechem. This was the deepest well in the Holy Land (39 metres). When interpreted, this encounter is often compared to the love story of Jacob and Rachel..$^{37}$ Jesus asks the Samaritan woman for the love that is concealed in her heart. However, this is not about physical love, but the expression of spiritual love for one's neighbour, even if they come from another community despised by the Jews. That love is eternal, and the water that Jesus gives is the living water.

The most famous lake in Palestine is the Sea of Galilee. In Hebrew it is called Kineret, which means 'lyre' (because its shape is reminiscent of the instrument). ${ }^{38}$ The Gospel writers use several names for the lake, and some call it a 'sea', probably

${ }^{34}$ F. Gryglewicz, Ewangelia według św. Łukasza, Poznań-Warszawa 1974, Pallottinum, p. 117.

${ }^{35}$ F. Gryglewicz, Ewangelia według św. Łukasza, Poznań-Warszawa 1974, Pallottinum, p. 117.

${ }^{36}$ K. Višaticki, Z. Pažin, Živa Voda - Majim Hajim: Teološko značenje vode i njezina uloga u spasenju svijeta (Living Water - Majim Hajim: The Theological Significance of Water and Its Role in Saving the World), Zagreb 2008, Hrvatsko biblijsko društvo - Teovizija, pp. 104-105. The Hebrew word 'ajin has multiple meanings. It usually denotes a source, with the derivative majan, which indicates the place of the source.

${ }^{37}$ P. R. Gryziec, Spotkania przy studni. Rozważania o teologii św. Jana, Kraków 2000, Wyd. OO Franciszkanów, p. 91; R. Fabris, Giovanni, Roma 1992, Edizioni Borla, p. 295. In this context, it is a Judaic interpretation of a biblical text that consists of interpreting one passage through another. This interpretation is called gezer szawa.

${ }^{38}$ R. E. Brown, Znanstveni uvod u Bibliju (Scientific Introduction to the Bible), Sarajevo and Zagreb 2012, Katolički bogoslovni fakultet (Catholic Faculty of Theology) and Glas Koncila, p. 360 . 
due to its importance in supplying the surrounding population with fish and its importance in other activities, in an area which did not have a great deal of rainfall or any larger, deeper surface waters. In Matthew (Mt 14:34) we read about the region of Gennesaret, and Luke writes about the Lake of Gennesaret (Lk 5:1). In Matthew and Mark it is the Sea of Galilee, and in John it is Lake Tiberias (Jn 6:1; 21:1), after the town of Tiberias, the administrative seat of Galilee, which was named after the emperor Tiberius. ${ }^{39}$ The blue of the lake exudes calm, but sudden storms are possible, especially in summer (Mt 8:24; Mk 4:37; Lk 8:23)..$^{40}$ There Jesus prayed ( $M k 1: 35 ; 6: 64$ ), and he certainly had to pass by the shores of the lake many times as he travelled from Nazareth or returned to his home in that Galilean settlement. Along the shores of the lake and on the lake itself, Jesus performed several miracles: miraculous fishing (Lk 5:4-6), walking on water (Mt 14:23-36; In 6:19), calming the storm (Lk 8:22-25), and the multiplication of the loaves (Jn 6:1-21). Capernaum is located near the lake, and was an important base for Jesus' work ( $\operatorname{Lk} 4: 31$; Jn 2:12).

Pools are also mentioned in the Gospels. They are associated with Jesus' miracles, particularly the healing of the blind and lame. They include Siloam (Siloe, Siloah) and Bethesda. Siloam was an underground tunnel, half a kilometre long, through which water from the nearby spring of Gihon was delivered to Jerusalem. The pool took its name from the tunnel. The pool was located at the foot of Mount Zion next to the Sheep Gate (Jn 5:1-2), and was about 16 metres long and 5 metres wide..$^{41}$ From the Gospel of Luke we know that there was a tower located next to it that collapsed in Jesus' time and killed 18 people. John (Jn 9:1) states that this pool was also called the 'Sent', which actually has the same meaning as the Hebrew word siloah. In this pool, Jesus healed a man blind from birth (Jn 9:1-41). The second pool is also described in the Gospel of John. This is Bethesda (Jn 5:2), which had five porches. 'Bethesda' means 'house of mercy'. It was here that Jesus healed the lame man. ${ }^{42}$ Many people

${ }^{39}$ R. E. Brown, Znanstveni uvod u Bibliju (Scientific Introduction to the Bible), Sarajevo and Zagreb 2012, Katolički bogoslovni fakultet (Catholic Faculty of Theology) and Glas Koncila, p. 360 .

${ }^{40}$ J. Burić, Život i običaji Svete zemlje u Isusovo vrijeme (The Life and Customs of the Holy Land at the Time of Jesus), Split 1998, Crkva u svijetu (Church in the World), p. 170.

${ }^{41}$ J. Burić, Život i običaji Svete zemlje u Isusovo vrijeme (The Life and Customs of the Holy Land at the Time of Jesus, Split 1998, Crkva u svijetu (Church in the World), p. 166.

${ }^{42}$ J. Burić, Život i običaji Svete zemlje u Isusovo vrijeme (The Life and Customs of the Holy Land at the Time of Jesus, Split 1998, Crkva u svijetu (Church in the World), p. 166. 
gathered near pools, including those who were forced to beg due to their health problems and lower social status. In this atmosphere, Jesus strove to approach the weakest and the socially marginalized, who in the orbit of Jerusalem, the spiritual centre of the Jews, wanted to touch at least part of the prosperity they were denied. Through Jesus' divine intervention by the pools, they gained hope against all hope (cf. Rom 4:18).

Unlike streams, seas and oceans are mentioned far less frequently in the Bible. In the Old Testament they generally had negative connotations ${ }^{43}$ For the Jews, farmers, and shepherds in the Mediterranean hinterland, the sea was regarded as an 'abyss' of unclean waters in which original chaos reigned and continued to threaten the organisation of the world (see Gen 1:2; Job 26:7; etc.).

It is significant that the Gospels do not record that Jesus resided on the shores of the Mediterranean. This is a reflection of the fact that in ancient times, the Jews did not value the sea as a source of life and a medium of communication. A maritime orientation can only be traced in the period of Solomon's reign, when he had a fleet built for the expansion of trade which, until then, had been limited to neighbouring regions (Solomon's main naval centre was Elath on the shores of the Gulf of Aqaba in the Red Sea; cf. 2 Chr 8:17-18). However, even at the time of its greatest prosperity, the Jewish state failed to achieve the status of an established naval power, because access to the Mediterranean coast and precious naval centres were jealously guarded by the Phoenicians and the Philistines. Nevertheless, Jews gradually emigrated to cities throughout the Mediterranean, establishing communities among which Paul and the other apostles had the opportunity to spread the Good News.

\subsection{Symbolism of the anthropogenic landscape in the Bible}

An important geographical basis that affects socio-economic activities in the Holy Land, is the climate. According to Köppen's classification, in the north and northwest of the Holy Land (Galilee and Samaria), the climate is the Csa type (Mediterranean climate with dry hot summers, the 'olive' climate), the central part (a smaller part of Judea) has characteristics of the BSh type (hot steppe climate), and the southern part (most of Judea and Idumea) has a BWh

${ }^{43}$ P. Kang-Kul Cho, The Sea in the Hebrew Bible: Myth, Metaphor, and Muthos, Doctoral dissertation, Cambridge, MA, 2014, Harvard University. 
climate (hot desert climate).$^{44}$ While Galilee is a pleasant area with a Mediterranean olive climate, the bulk of the Holy Land is an area of aridity dominated by desert and steppe landscapes. In such a semi-arid and arid area, which is also predominantly hilly, the history of habitation is marked by olive growing and viticulture in the Mediterranean zone, and farming and animal husbandry in the rest of the Holy Land. It was these activities that had affected the shaping of the landscape and the spatial and social organization of the rural populations over thousands of years, while cities, in addition to being the headquarters of organised agricultural production, largely based their development on crafts and trade. The social system of agricultural production in agrarian communities holds in high regard to the family and property, which are indivisible and form an economic entity. The attitude of the family towards the property as the very basis of existence is extremely important, and is crucial for the survival of all the members of the community and for its biological renewal..$^{45}$ The family was the central social institution in biblical times; consequently family ties shaped economic relations. Thus, of the 242 species and varieties of plants mentioned in the Bible, over $50 \%$ of them had economic significance. ${ }^{46}$ Given the climate and soil conditions, grapes, olives and figs were of particular importance.

According to archaeological evidence, the cultivation of vines in the Holy Land can be traced back to the early Bronze Age. ${ }^{47}$ In the books of the Old Testament, Israel is compared to a vineyard. The vine was engraved on Jewish coins, and the golden vine that hung on the front of the temple reminded the Jews of their covenant with God. ${ }^{48}$ In the New Testament, Jesus often uses the image of a vineyard in his teaching (vineyard - á $\mu \pi \varepsilon \lambda \omega \dot{\omega} v$; vine - ä $\mu \pi \varepsilon \lambda \circ \varsigma$ ). Vineyards were surrounded by stone walls up to two metres high (drystone walls). Thorns

${ }^{44}$ D. Zoccatelli, F. Marra, M. Armon, Y. Rinat, J. A. Smith, E. Morin, Contrasting rainfallrunoff characteristics of floods in desert and Mediterranean basins, "Hydrology and Earth System Sciences" 23 (2019) 6, pp. 2665-2678.

${ }^{45}$ J. Defilippis, Razvoj obiteljskih gospodarstava Hrvatske i zadrugarstvo (Development of Croatian Family Farms and Cooperatives, "Sociologija sela" (Rural Sociology) 43 (2005) 1, pp. 43-59.

${ }^{46}$ H. N. Moldenke, The Economic Plants of the Bible, "Economic Botany" 8 (1954) 2, pp. 152-163.

47 J. A. Seely, The Fruit of the Vine: Wine at Masada and in the New Testament, "BYU Studies Quarterly" 36 (1996) 3, pp. 207-227.

${ }^{48}$ J. Burić, Život i običaji Svete zemlje u Isusovo vrijeme (The Life and Customs of the Holy Land at the Time of Jesus), Split 1998, Crkva u svijetu, p. 160. 
were placed along the tops of the walls (Mt 21:33). These constructions protected the vineyard from soil erosion, and also from thieves and animals. There were grape presses in larger vineyards. In many vineyards, an observation tower was built, along with a shed for viticulture tools. There was a terrace from which the vineyard keeper watched the ripening of the grapes (Mt 21:33) ${ }^{49}$ Jesus' parables correspond to prophetic descriptions of vineyards (Mt 21:33-43 and Isa 5:1-7). Using the literary form of the parable (Mt 21:33-43), Jesus used metaphors and parables to identify himself with the vine (Jn 15: 1-8): „I am the true vine, and my Father is the gardener" (Jn 15:1). Just as an individual stem receives the sap of life from the vine, so believers receive mystical life from their communion with Christ and the Father.An important fact is that Jesus does not use the word 'like' in his speech, but says, "I am the vine". This expresses the direct connection between God and man. The gardener is the Father who cares for the vine so that it may bear more fruit. In the parable of the beloved son, the master sends his son into his vineyard, where he is killed by the wicked tenants (Mk 12:1-12; Lk 20:9-19, Jn 20:9-19).

Vineyards are associated with wine production; an important commodity. Along with grain and oil, wine is the most common agricultural product in the Holy Land. According to Ps 104:15 and Judges 9:13, wine „brightens the heart of man". Therefore, wine is an element of the messianic feast, and above all, it is a sign of the Eucharistic feast in which the believer draws joy from its source: in the love of Christ. The figurative cheering of the human heart becomes a reality in the Eucharist. The wine becomes the blood of Christ. ${ }^{50}$

The olive is the most important tree grown in the Holy Land. The Gospels do not mention the actual word 'olive', but it always appears in a particular context. In addition, Paul's epistle to the Romans (Rom 11:17-24) uses the image of an olive tree, with broken branches and grafted twigs, as an admonition to Christians of pagan origin to indicate their excessive pride.

Jesus speaks of olive oil in Luke 16:6, and in describing his solemn entry into Jerusalem, the Gospel writers state that people threw olive branches in front of Jesus. The most famous place where an olive grove is mentioned is the Mount of Olives, where Jesus went with his disciples and endured much

${ }^{49}$ J. Burić, Život i običaji Svete zemlje u Isusovo vrijeme (The Life and Customs of the Holy Land at the Time of Jesus), Split 1998, Crkva u svijetu, p. 161.

${ }^{50}$ X. L. Dufour, Rječnik biblijske teologije (Dictionary of Biblical Theology), Zagreb 1980, Kršćanska sadašnjost, p. 414. 
agony. However, the evangelists do not agree on the particulars of the name of this place which is found outside the city, though it is clearly the Mount of Olives. Matthew calls it a 'hamlet' (26:36), Mark a 'property' (14:23), and John calls it a 'garden' (18:1).

While the mention of olive oil is rare in the New Testament, there are plenty of references to this olive product in the Old Testament. Oil is a gift from God along with grain and wine. Oil is a sign of God's blessing (Deut 7:13; Jer. 31:12), and the lack of it means punishment for unbelief (Micah 6:15), while the abundance of olive oil is a sign of salvation (Joel 2:19) and a sign of eschatological bliss (Hos 2:24). Oil is a symbol of God's blessing, while the green olive is a symbol of the righteous blessed by God (Ps 52:10). Oil is a pleasant ointment that indicates betrothal love (Song 1:3) and friendship (Prov 27:9). It is also a symbol of fraternal and family harmony (Ps 133:2). Furthermore, oil is a symbol of joy and oil makes the face shine (Ps 104:15). In the Church, oil is used during the sacraments: baptism, anointing of the sick, confirmation and ordination..$^{51}$

The fig ( $\sigma v \kappa \tilde{\eta})$ is also a very popular tree in the Holy Land due to its fruit, the shade it provides, and for its use in the vineyard for protection against pests. Rabbis often meditated and taught under fig trees. The fig tree in the Holy Land has two yields each year: an early crop and a late crop. The early fruit grows in early spring on the shoots of the previous year before the fig grows new leaves, and the late fruit develops in November or December. This late fruit stays on the tree during the winter and is harvested in the spring. Therefore, figs from the tree can be eaten during ten months of the year. Figs thrive on poor, rocky soil, and begin to bear their first fruits three years after planting..$^{52}$ According to Mark's account (Mk 11:13), Jesus saw a fig tree "from afar" on which there was no fruit. It seems odd that he was surprised, since he was looking for fruit at a time when the fig trees were not bearing fruit. Jesus probably knew full well that it was not the time to pick the fruits/figs. This fact is associated with many fig trees which were planted in front of almost every house. This paradox can be explained theologically rather than in agricultural terms. There were leaves on the tree, so it could be expected that there would be fruit, even if inedible. However, there

${ }^{51}$ X. L. Dufour, Rječnik biblijske teologije (Dictionary of Biblical Theology), Zagreb 1980, Kršćanska sadašnjost, pp. 1388-1389.

${ }^{52}$ H. N. Moldenke, The Economic Plants of the Bible, "Economic Botany" 8 (1954) 2, pp. $152-163$. 
was none. Many interpreter ${ }^{53}$ of this passage allegorically compare the infertility of the fig tree with the infertility and barrenness of the Jewish leaders, and the need for faith among Jesus' disciples. Jesus' conversation with Nathanael implies that the fig tree mentioned had lush leaves (Jn 1:47). Figs, olives and vines were all agricultural crops that required people to cultivate them.

There are many references to agricultural production in the New Testament. In the parables, Jesus metaphorically points to the problems of sowing seed, from those that fall on rocky ground or thorns and do not produce anything, to those that fall on fertile ground and bear much fruit (Mt 13:18-23; Mk 4:3-20, Lk 8;4-15). The key words, however, are found in the Gospel of John: "Very truly I tell you, unless a kernel of wheat falls to the ground and dies, it remains only a single seed. But if it dies, it produces many seeds". (Jn 12:24).

Given the importance of animal husbandry in the Holy Land, the motifs of the pastoral landscape are extremely common in many biblical texts. These motifs often directly link the Old and New Testaments, as prototypes of God's revelation in the New Testament appear in the Old Testament. For example, the sacrifice of Jesus is prefigured in Abraham's sacrifice of his son Isaac and the Passover sacrificial lamb, which was to be the firstborn, healthy and without blemish, commemorating the exodus of the chosen people from Egypt. In his fourth song about the Servant of the Lord, the prophet Isaiah prophesised what was to happen to the Son of God: “... he was led like a lamb to the slaughter", (Isa 53:6-7). John the Baptist joins him in prophecy: „Behold the Lamb of God who takes away the sin of the world" (Jn 1:29). However, pastoral scenes surround Jesus even at the moment of his birth, which takes place in a stable, away from the urban bustle and lights, in a place where shepherds watched over their sheep. These shepherds are the first to visit the incarnate Word ( $\mathrm{Lk} 2: 8-20$ ). The rural landscape is a key element in the staging of the birth of the Son of God. It is not just a backdrop or scenography full of idyllic pastoral images, but a dynamic setting in which shepherds play an important role.

The relationship between the faithful and God in the Gospels is often compared to the relationship between sheep and shepherds. Jesus takes pity on the people „because they were crushed and neglected like sheep without a shepherd” (Mt 9:36), and rejoices in the lost sheep (Lk 15:1-7) which he saves and carries

${ }^{53}$ R. Schnackenburg, Evandelje po Marku (Gospel of Mark), Volume 2, Zagreb 2018, Glas koncila, pp. 128-131; G. Vigini, Ewangelie i Dzieje Apostolskie, Poznań 1999, Wyd. Paulistki, p. 228. 
on his shoulders. He does this because he takes on the role of a good shepherd: "I am the good shepherd. The good shepherd lays down his life for the sheep" (Jn 10:11).

\section{Conclusion}

The Bible, with its multiple meanings and influences, is an inexhaustible source of geographical, historical, literary, philosophical and spiritual information. Although its primary aim as a holy book is to form religious consciousness, it is also an important medium of information about space and time. In this context, this paper considers the biblical rural and suburban landscape of the Holy Land, which has a symbolic meaning in the light of the above. This primarily refers to the natural elements of the landscape, but also to the anthropogenic elements of the cultural landscape mentioned in the New Testament. Through centuries of social, economic and religious influence, the natural and cultural elements of the landscape have become intertwined. This bond is particularly strong in agrarian areas. Thus, the symbolism of natural and social elements of the landscape runs throughout the Bible. It is especially emphasized in the New Testament through the Gospels, which describe the life of Jesus Christ in which the everyday landscape of rural and suburban spaces takes on elements of holiness. Throughout the New Testament, the manifestation of holiness is seen in heights and waters, but also in wine and olive oil. Thus, the inscribed natural and anthropogenic landscape elements in the Bible are present in the long term in their various forms in the new creation of the landscape which, in addition to visual or physiognomic functions, has a key purpose in creating an imaginary geography, in which real spatial forms and phenomena take on a special religious significance. They form the basis of key motifs in Christianity that have found expression in liturgy, painting and architecture (the good shepherd, the Passover lamb, bread and wine, oil, etc.) and content that attracts believers through its holiness, in order to establish direct contact with the space in which Jesus Christ lived and acted. Jesus' presence sanctified many places in the Holy Land which has been the focus of many pilgrimages from all continents for the last two millennia. 


\section{Bibliography}

Aharoni Y., The Land of the Bible. A Historical Geography. Translated from the Hebrew and edited by A. F. Rainey, Philadelphia 1979, Westminster Press.

Alphin G., A New Testament Geography: Description, Perspectives, and Implications for the Field of Geography, Baton Rouge, 2001, Louisiana State University.

Anderson E. P., Jackson S., Tharme R. E., Douglas M., Flotemersch J. E., Zwarteveen M., Lokgariwar C., Montoya M., Wali A., Tipa G. T., Jardine T. D., Olden J. D., Cheng L., Conallin J., Cosens B., Dickens C., Garrick D., Groenfeldt D., Kabogo J., Roux D. J., Ruhi A., Arthington A. H., Understanding rivers and their social relations: A critical step to advance environmental water management, WIREs Water, 2019; 6:e1381, pp. 1-21.

Bellentani F., Landscape as text. in: Higuera C. J. R., Bennett T. J. (eds.), Concepts for Semiotics, Tartu 2016, University of Tartu Press, pp. 76-87.

Brown R. E, Znanstveni uvod u Bibliju (Scientific Introduction to the Bible), Sarajevo and Zagreb 2012, Katolički bogoslovni fakultet (Catholic Faculty of Theology) and Glas Koncila.

Burić J., Život i običaji Svete zemlje u Isusovo vrijeme (The Life and Customs of the Holy Land at the Time of Jesus), Split 1998, Crkva u svijetu (Church in the World).

Casti E., Towards a theory of interpretation: cartographic semiosis, "Cartographica: The International Journal for Geographic Information and Geovisualization" 40 (2005) 3, pp. 1-16.

Cocagnac M., Biblijski simboli (Biblical Symbols), Zagreb 2002, Antibarbarus.

Cosgrove D., S. Daniels, The Iconography of Landscape, Cambridge 1988, Cambridge University Press; W. Norton, Cultural Geography, Oxford 2006, Oxford University Press.

Davis E. F., Scripture, Culture, and Agriculture, Cambridge 2008, Cambridge University Press.

Defilippis J., Razvoj obiteljskih gospodarstava Hrvatske i zadrugarstvo (Development of Croatian Family Farms and Cooperatives, "Sociologija sela" (Rural Sociology), 43 (2005) 1, pp. 43-59.

Dewsbury J. D., Cloke P., Spiritual landscapes: existence, performance and immanence, "Social \& Cultural Geography" 10 (2009) 6, pp. 695-707.

Dickson J. R., Deserts of Development: How God Shapes His Leaders in the Wilderness, Doctoral dissertation, Lynchburg, 2009, Liberty University.

Dozeman T. B., Biblical Geography and Critical Spatial Studies, in: Berquist J. L., Camp C. V. (eds.), Construction of Space I: Theory, Geography and Narrative, Library of Hebrew Bible - Old Testament Studies, 481, New York and London 2008, T\&T Clark, pp. 87-108.

Dufour X. L., Rječnik biblijske teologije (Dictionary of Biblical Theology), Zagreb 1980, Kršćanska sadašnjost.

Fabris R., Giovanni, Roma 1992, Edizioni Borla. 
Fouilloux D., Rječnik Biblijske culture (Dictionary of Biblical Culture), Zagreb 1999, AGM.

France R. T., A tale of two mountains: mountains in biblical spirituality, "Rural Theology" 6 (2008) 2, pp. 117-125.

Grabner-Haider A. (ed.), Praktični biblijski leksikon (A Practical Biblical Lexicon), Zagreb 1997, Kršćanska sadašnjost, pp. 340-341.

Gryglewicz F., Ewangelia według św. Łukasza, Poznań-Warszawa 1974, Wyd. Pallottinum.

Gryziec P. R., Spotkania przy studni. Rozważania o teologii św. Jana, Kraków 2000, Wyd. OO Franciszkanów.

Haensch R., The Roman Provincial Administration, in: Hezser, Catherine (ed.), The Oxford Handbook of Jewish Daily Life in Roman Palestine, Oxford 2010, Oxford University Press, pp. 71-84.

Har-El M., Landscape nature and man in the Bible: sites and events in the Old Testament, Jerusalem 2003, Carta.

Kang-Kul Cho P., The Sea in the Hebrew Bible: Myth, Metaphor, and Muthos, Doctoral dissertation, Cambridge, MA, 2014, Harvard University.

Kong L., Religious Landscapes, in: J. S. Duncan; N. C. Johnson, R. H. Schein (eds.), A Companion to Cultural Geography, Malden, Oxford and Carlton 2004, Blackwell Publishing, pp. 365-381.

Kraft S. E., The making of a sacred mountain. Meanings of nature and sacredness in Sápmi and northern Norway, "Religion" 40 (2010), pp. 53-61.

McGinn B., Ocean and Desert as Symbols of Mystical Absorption in the Christian Tradition, "The Journal of Religion" 74 (1994) 2, pp. 155-181.

Moldenke H. N., The Economic Plants of the Bible, "Economic Botany” 8 (1954) 2, pp. 152 163.

Moxnes H., Landscape and Spatiality: Placing Jesus, in: D. Neufeld, R. De Maris (eds.), Understanding the Social World of the New Testament, New York 2010: Routledge, pp. 90-106.

Moxnes H., Placing Jesus of Nazareth: Toward a Theory of Place in the Study of the Historical Jesus, in S. G.Wilson, M. Desjardins (eds.), Text and Artifact in the Religions of Mediterranean Antiquity: Essays in Honour of Peter Richardson, Waterloo 2000, Wilfred Laurier University, pp. 158-175.

Moxnes H., The Construction of Galilee as a Place for the Historical Jesus - Part I, "Biblical Theology Bulletin" 31 (2001) 1, pp. 26-37.

Moxnes H., The Construction of Galilee as a Place for the Historical Jesus - Part II, "Biblical Theology Bulletin" 31 (2001) 2, pp. 64-77.

Park Ch. C., Religion and geography, in: J. R. Hinnells (ed.), The Routledge Companion to the Study of Religion, London 2004, Routledge, pp. 439-455.

Park Ch. C., Sacred worlds. An Introduction to geography and religion, London and New York 1994, Routledge.

Piccirillo M., Ricerca archeologica e Vangelo e i Luoghi Santi di Palestina, "Cauriensia" 3 (2008), pp. 53-91. 
Šakaja L., Uvod u kulturnu geografiju (Introduction to Cultural Geography), Zagreb 2015, Leykam international.

Sauer C., The Morphology of landscape, in: J. Sgnew, D. N. Livingstone, A. Rogers (eds), Human Geography. An Essential Anthology, Oxford 1996 [1925], Blackwell.

Schnackenburg R., Evanđelje po Marku (Gospel of Matthew), Volume 2, Zagreb 2018., Glas koncila.

Schreiner P., Space, place and biblical studies: A survey of recent research in light of developing trends, „Currents in Biblical Research” 14 (2016) 3, pp. 340-371.

Seely J. A., The Fruit of the Vine: Wine at Masada and in the New Testament, „BYU Studies Quarterly", 36 (1996) 3, pp. 207-227.

Sopher D. E., Geography of religions, Englewood Cliffs 1967, Prentice-Hall, pp. 24-46.

Stewart E. C., Gathered Around Jesus: An Alternative Spatial Practice in the Gospel of Mark, Cambridge, 2009, James Clark and Co.

Stewart E. C., New Testament space/spatiality, „Biblical Theology Bulletin” 42 (2012) 3, pp. 139-150.

Stokowski P., Symbolic Aspects of Water, in: S. F. McCool, R. N.Clark, G. H. Stankey (eds.), Water and people: challenges at the interface of symbolic and utilitarian values, Gen. Tech. Rep. PNW-GTR-729. Portland 2008, Portland, OR: U.S. Department of Agriculture, Forest Service, Pacific Northwest Research Station, pp. 19-60.

Vigini G., Ewangelie i Dzieje Apostolskie, Poznań 1999, Wyd. Paulistki.

Višaticki K., Pažin Z., Živa Voda - Majim Hajim: Teološko značenje vode i njezina uloga u spasenju svijeta (Living Water - Majim Hajim: The Theological Significance of Water and Its Role in Saving the World), Zagreb 2008, Hrvatsko biblijsko društvo - Teovizija.

Vonder Bruegge J., Mapping Galilee in Josephus, Luke, and John. Critical Geography and the Construction of an Ancient Space, Ancient Judaism and Early Christianity, Volume 93, Leiden and Boston 2016, Brill.

Zoccatelli D., Marra F., Armon M., Rinat Y., Smith J. A., Morin E., Contrasting rainfallrunoff characteristics of floods in desert and Mediterranean basins, "Hydrology and Earth System Sciences" 23 (2019) 6, pp. 2665-2678. 